\title{
INFLUENCE OF DIETARY INTAKES, 'WASH' AND DIARRHEAL MORBIDITY ON STUNTING AMONG CHILDREN BELOW FIVE YEARS IN NAKURU COUNTY: A CASE STUDY OF KAPTEMBWO AND MILIMANI, KENYA
}

\author{
Daniel Matoke Ayienda ${ }^{1,2 i}$, \\ Muthuka J. Kyalo², \\ Job O. Mapesa ${ }^{1}$, \\ Lawrence Mugambi ${ }^{1}$, \\ Eglah J. Kiplagat ${ }^{2}$ \\ ${ }^{1}$ Kenya Methodist University, \\ Nairobi, Kenya \\ ${ }^{2}$ Kenya Medical Training College, \\ Nairobi, Kenya
}

\begin{abstract}
:
Stunting is the most prevalent and pervasive form of under nutrition worldwide. In 2019, an estimate of 144 million (21.3\%) of children under the age of 5 years are stunted globally. In sub-Saharan Africa, 34\% of children fewer than 5 years are stunted and the burden of stunting is most prevalent in the Eastern Africa region with 37\% (FAO, 2017). In Kenya, out of a total of 7 million under 5 years, 1.82 million (26\%) children are suffering from stunting; out of which $11.4 \%$ are severely stunted. Stunting is associated with greater risk of death from infectious diseases in childhood, poorer cognition, poorer educational outcomes and lower adult earnings. The study population was a total of 314 children aged 0-59 months. Data was collected using survey CTO questionnaire. Use of pesticides, hygiene practices and sanitation (human waste disposal), hand washing practices, water sources and means of water treatment were examined and adequately described in relation to EED and stunting. Survey CTO programme was installed in tablets and or smart phones, in which a questionnaire with closed ended questions was programmed and used to collect a no-paper work data. The Survey CTO programmed questionnaire only allowed the researcher to key in a response for one question before moving to the next question. Data was analyzed using SPSS version 22 software. Descriptive analysis was done using SPSS while regression was done using STATA. There was no significant difference in dietary intakes between children in Kaptembwo and Milimani, and that the dietary intakes in both Milimani and Kaptembwo were adequate and balanced. Out of
\end{abstract}

i Correspondence: email danayienda2026303@gmail.com 
202 children sampled in Kaptembwo, 40.59\% had experienced diarrhea in the last four weeks to data collection while out of 112 children sampled in Milimani, only $17 \%$ had experienced diarrhea in the last four weeks. In spite of the same dietary intakes in Kaptembwo and Milimani, stunting is high in Kaptembwo than in Milimani. Out of a total of 314 child ren sampled, $25 \%$ were stunted in Kaptembwo, while only $3.33 \%$ were stunted in Milimani. Diarrhea increases loss of dietary nutrients thereby making the nutrients required for growth inadequate. High level of stunting in Kaptembwo is associated with poor environmental conditions (poor sanitation and hygiene) which contribute to diarrhea. Diarrhea could be key contributor to Environmental Enteric Dysfunction (EED), which is too a contributor to stunting. It is recommended that residents of Kaptembwo and Milimani are educated on the importance of good sanitation and hygiene in order to curb diarrhea, which is a contributor to the development of EED. In the same spirit, understand the importance of proper use of pesticides. Experimental research was done in the same area involving the use of biological markers for EED.

Keywords: Environmental Enteric Dysfunction (EED), stunting, diarrheal morbidity

\section{Introduction}

Stunting is the most prevalent and pervasive form of under-nutrition worldwide (Prendergast \& Humphrey, 2014). An estimate of 144 million (21.3\%) of children under the age of 5 years are stunted globally (UNICEF (2019). In sub-Saharan Africa, 34\% of children fewer than 5 years are stunted and the burden of stunting is most prevalent in the Eastern Africa region with 37\% (Nshimyiryo et al., 2015). In Kenya, out of a total of 7 million children under 5 years, 1.82 million (26\%) children are stunted, out of which $11.4 \%$ are severely stunted (Below -3 Standard deviation) (KNBS, 2015). Stunting is associated with greater risk of death from infectious diseases in childhood, poorer cognition, poorer educational outcomes and lower adult earnings (Caulfield et al. 2004; Alderman et al., 2006; Grantham-McGregor et al., 2007; Maluccio et al., 2009). The causes of stunting are postulated to be multi-factorial and include at least; inadequate prenatal nutrition and inadequate dietary intake early in life (first 1,000 days); chronic and repeated acute infections leading to a catabolic inflammatory state; and the chronic intestinal inflammatory condition known as Environmental Enteric dysfunction (EED). EED is a subclinical syndrome characterized by mucosal inflammation, reduced barrier function, villous blunting and reduced absorptive capacity in the small intestine (Crane et al., 2015). EED is established during infancy and is associated with poor sanitation, certain gut infections, micronutrient deficiencies, all of which may ultimately lead to chronic malnutrition (stunting), wasting and reduced vaccine efficacy among children living in low-resource settings (Crane et al., 2015). EED was first described among adult Corps volunteers returning from deployment to low-and middle-income countries (LMIC) in the 1960s who presented with unexplained, persistent weight loss. Despite non-specific, 
clearly identifiable infectious etiology, biopsies of intestinal tissues in these individuals demonstrated morphological changes suggestive of chronic enteric infection (Lindenbaum et al., 1966; Keusch et al., 1972). The symptoms of these volunteers usually resolved within several months of returning to the USA, further supporting the link between these histological changes and recurrent exposure to pathogens in areas of poor sanitation and hygiene (Lindenbaum et al., 1971; Lindenbaum et al., 1973). Studies have observed that EED is absent in some tropical populations of high socioeconomic status, such as Qatar and Singapore. These findings demonstrate that environmental conditions were critical drivers of EED, instead of geographical position (Prendergas and Kelly, 2012).

Many studies done on stunting have, in many cases, focused on poor nutrient intake as the principal cause of stunting, attaching little emphasis on Environmental enteric dysfunction(EED). Poor sanitation and hygiene is a classical environment for development of EED. Studies have also revealed that higher cumulative burden of diarrhea before the age of 2 years is associated with greater odds of being stunted at 2 years (Checkley et al. 2008).This study found that diarrhoeal episodes were high in Kaptembwo (40.59\%) than in Milimani (17\%). Despite children in Kaptembwo and Milimani taking nutritionally adequate diets, without any significant difference, stunting was higher in Kaptembwo (25\%) than in Milimani (3.33\%). The high episodes of diarrhea of children in Kaptembwo lead to loss of nutrients from the GIT due to short transient time or due to mal-absorption as a result of villous atrophy, associated with EED. Children taking adequate diets end up being stunted due to the effects of environmental factors. These findings demonstrated that nutritionally adequate diet is necessary but not enough for ensuring optimal linear growth, and that environmental conditions (poor water, sanitation, and hygiene), associated with the development of EED could play a significant role in stunting (Mbuya \& Humphrey, 2016).

\section{Materials and Methods}

The present study was conducted in Kaptembwo informal settlement and Milimani estate both located in Nakuru County, Kenya. The study design was a comparative study and adopted descriptive cross-sectional approach which ensured complete description of the situation, making sure that there is minimum bias in the collection of data. The tool was pre-tested by the principal investigator and the research assistants and adjusted accordingly before it was used in the actual data collection.

The study targeted children under the age of five years. The study area is estimated to have a total population of 106,123 (Kaptembwo 43,521 in area of $5.1 \mathrm{~km}^{2}$ and Milimani 26,643 in area of $20.9 \mathrm{~km}^{2}$ (KNBS, 2019).

The two study areas (Kaptembwo and Milimani) were clustered accordingly in readiness for data collection. Kaptembwo was clustered into 10 big clusters, each with between 30-35 dwellings or plots. Systematic random sampling was used to sample 10 
dwellings from each cluster. Purposive sampling method was used to select at least 2 households with a child 0-59 months from each dwelling or plot; thereby making the final sample 202 children.

In Milimani, households were clustered into 14 clusters of between 15-20 households per cluster. Purposive sampling method was used to select at least 8 households with a child 0-59 months, per cluster, making the total sample for Milimani 112 children. The study population was a total of 314 children aged 0-59 months. Data was collected using survey CTO questionnaire. The study variables; for example dietary intakes, the use of pesticides, hygiene practices and sanitation (human waste disposal), hand washing practices, water sources and means of water treatment were examined and adequately described in relation to EED and stunting.

Survey CTO programme was installed in tablets and or smart phones and used in the collection of a no-paper work data. A questionnaire with closed ended questions was programmed using Survey CTO into the tablets and or smart phones. The programme required that each research assistant log in using his personal details before accessing the questionnaire.

The Survey CTO programmed questionnaire only allowed the researcher to key in a response for one question before moving to the next question. In cases where for example the answer to a question was ' $\mathrm{No}^{\prime}$, the programme skipped all other questions which could only be responded to if the answer was 'Yes'. This helped a lot in saving time and allowed the researcher to collect the available data within a short period of time.

Three hundred and fourteen children aged between 00 months and 58 months were sampled. Survey CTO platform was used to collect data on diarrheal morbidity, socioeconomic and socio-demographic factors, dietary intake patterns, hygiene and sanitation, use of pesticides and water treatment and anthropometry. Data was analyzed using SPSS version 22 software. Descriptive analysis was done using SPSS while regression was done using STATA. Excel was used to do descriptive analysis and in the generation of appropriate graphs.

\section{Results and Discussion}

\subsection{Socio-demographic characteristics of children aged 0-59 months at Kaptembwo and Milimani}

A total of 314 children aged between 0-59 months were sampled and consisted of 162 $(51.59 \%)$ male and 152 (48\%) female children with an average age of 24.5 months and the mean height of 81.82 centimeters, as shown in Table 1 below. 
Daniel Matoke Ayienda, Muthuka J. Kyalo, Job O. Mapesa, Lawrence Mugambi, Eglah J. Kiplagat INFLUENCE OF DIETARY INTAKES, ‘WASH' AND DIARRHEAL MORBIDITY ON STUNTING AMONG CHILDREN BELOW FIVE YEARS IN NAKURU COUNTY: A CASE STUDY OF KAPTEMBWO AND MILIMANI, KENYA

Table 1: The demographic characteristics of children

\begin{tabular}{|l|c|c|c|c|c|}
\hline \multirow{2}{*}{$\begin{array}{l}\text { Target child } \\
\text { characteristics }\end{array}$} & \multicolumn{2}{|c|}{ Kaptembwo } & \multicolumn{2}{c|}{ Milimani } & Overall \\
\cline { 2 - 6 } & Male & Female & Male & Female & All children \\
\cline { 2 - 6 } & Mean & Mean & Mean & Mean & $\begin{array}{c}\text { Mean child } \\
\text { characteristics }\end{array}$ \\
\hline Age in months & 26.00 & 24.00 & 25.00 & 23.00 & 24.5 \\
\hline Height in cm & 82.54 & 80.01 & 83.84 & 80.90 & 81.82 \\
\hline
\end{tabular}

\subsection{Dietary practices}

There was no significant difference of food eaten by reference child between Milimani and Kaptembwo for all food types; $p$ values (Carbohydrates 0.79, Lipids 0.847, Proteins 0.0294, and Vitamins 0.905).

Table 2: Food group eaten by reference child in the last 24 hours

\begin{tabular}{|l|c|c|c|c|c|}
\hline Food group eaten by reference & Kaptembwo & Milimani & & & Overall \\
\cline { 2 - 6 } child in the last 24 hours & $\mathbf{n = 2 0 2}$ & $\mathbf{n = 1 1 2}$ & $\mathbf{c h 2}$ & P-value & $\mathbf{n = 3 1 4}$ \\
\hline Carbohydrates & 91.1 & 90.2 & 0.0713 & 0.79 & 90.8 \\
\hline Lipids & 89.1 & 88.4 & 0.0373 & 0.847 & 88.9 \\
\hline Proteins & 87.1 & 91.1 & 1.1034 & 0.294 & 88.5 \\
\hline Vitamins & 90.6 & 90.2 & 0.0144 & 0.905 & 90.4 \\
\hline
\end{tabular}

Table 3 below shows that children in Kaptembwo recorded high episodes of diarrhea (40.59\%) in the last four weeks compared to $(12.86 \%)$ who had diarrhea in the last four weeks in Milimani. The overall diarrhea episodes for Milimani and Kaptembwo were $29.23 \%$. $70.73 \%$ of the children who had diarrhea in Kaptembwo got treatment while $75 \%$ of the children who had diarrhea in Milimani got treatment. An average of $71.57 \%$ children who had diarrhea in Kaptembwo and Milimani got treatment.

Table 3: Episodes of diarrhea in the last 4 weeks and treatment for Kaptembwo and Milimani

\begin{tabular}{|l|c|c|c|}
\hline Area & Diarrhea percent (\%) & Area & Treatment (\%) \\
\hline Kaptembwo $(\mathrm{n}=202)$ & 40.59 & Kaptembwo $(\mathrm{n}=82)$ & 70.73 \\
\hline Milimani $(\mathrm{n}=112)$ & 17.86 & Milimani $(\mathrm{n}=20)$ & 75 \\
\hline Overall $(\mathrm{n}=314)$ & 29.23 & Overall $(\mathrm{n}=102)$ & 71.57 \\
\hline
\end{tabular}

\subsection{Contributors for diarrhea}

Through regression analysis, various dependent factors $(\mathrm{x})$ were tested using probit model against the independent variable (Diarrhea) (y), to establish the factors that significantly contributes to diarrhea in Kaptembwo and Milimani. Using probit model to assess the factors that contribute to diarrhea in Kaptembwo and Milimani at household level, the result show that buying Githeri and nuts from vendors, treatment with ORS, hand hygiene before eating, after eating, after defection/urination, after changing a child's nappy, availability of water at the site of washing hands, use of ventilated pit latrine and de-worming in every three months were key factors $(\mathrm{p}<0.05)$. 


\subsection{Levels of stunting}

\subsubsection{Height-for-age by gender Kaptembwo, Milimani}

Table 4 below shows the level of stunting for Kaptembwo is $25 \%$ while that of Milimani is $3.33 \%$. It was found that boys were more stunted than girls in both Kaptembwo (boys $15 \%$, girls $10 \%$ ) and Milimani (boys $2.50 \%$, girls $0.83 \%$ ). From this table, boys contributed more to the stunting percentages than girls in both cases (75\% boys Milimani, $60 \%$ boys Kaptembwo; 25\% girls Milimani, 40\% girls Kaptembwo).

Table 4: Height-for-age by gender in Kaptembwo and Milimani

\begin{tabular}{|l|c|c|c|}
\hline Description & $\begin{array}{c}\text { Percentage } \\
\text { for Stunting (\%) }\end{array}$ & Gender & $\begin{array}{c}\text { Contribution to } \\
\text { Stunting per gender (\%) }\end{array}$ \\
\hline \multirow{2}{*}{$\begin{array}{l}\text { Milimani } \\
(\mathrm{n}=112)\end{array}$} & \multirow{3}{*}{3.33} & $\begin{array}{c}\text { Boys } \\
2.50 \%\end{array}$ & 75 \\
\cline { 3 - 4 } & \multirow{2}{*}{25} & $\begin{array}{c}\text { Girls } \\
0.83 \%\end{array}$ & 25 \\
\hline $\begin{array}{l}\text { Kaptembwo } \\
(\mathrm{n}=202)\end{array}$ & $\begin{array}{c}\text { Boys } \\
(15 \%)\end{array}$ & $\begin{array}{c}\text { Girls } \\
(10 \%)\end{array}$ & 60 \\
\cline { 3 - 4 } & & & 40 \\
\hline
\end{tabular}

\subsubsection{Relationship of dietary intake and stunting in Kaptembwo and Milimani}

Figure 1 below shows that the Height-for-age values for many girls in Kaptembwo trails the height -for -age values for many girls in Milimani. The graph shows that there is high fluctuation in the nutritional status for children between 18-30 months and between 4654 months.

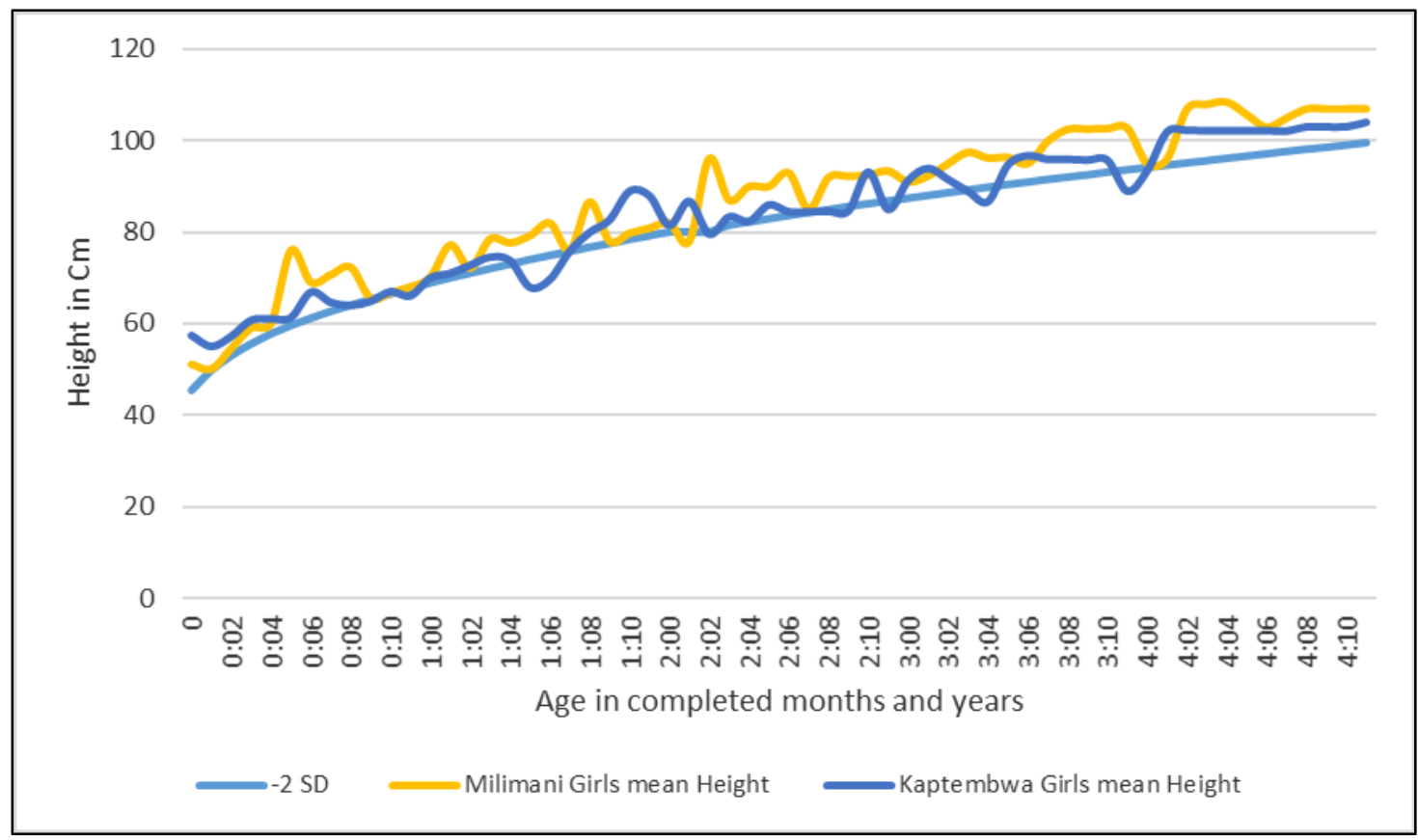

Figure 1: Height-for-age for girls in Kaptembwo and Milimani, Comparison of Actual Height with -2SD 
Figure 2 below shows that when the Height-for-age for boys in Kaptembwo and Milimani is compared, it is noted that the heights of many boys in Kaptembwo trails the heights of boys in Milimani.

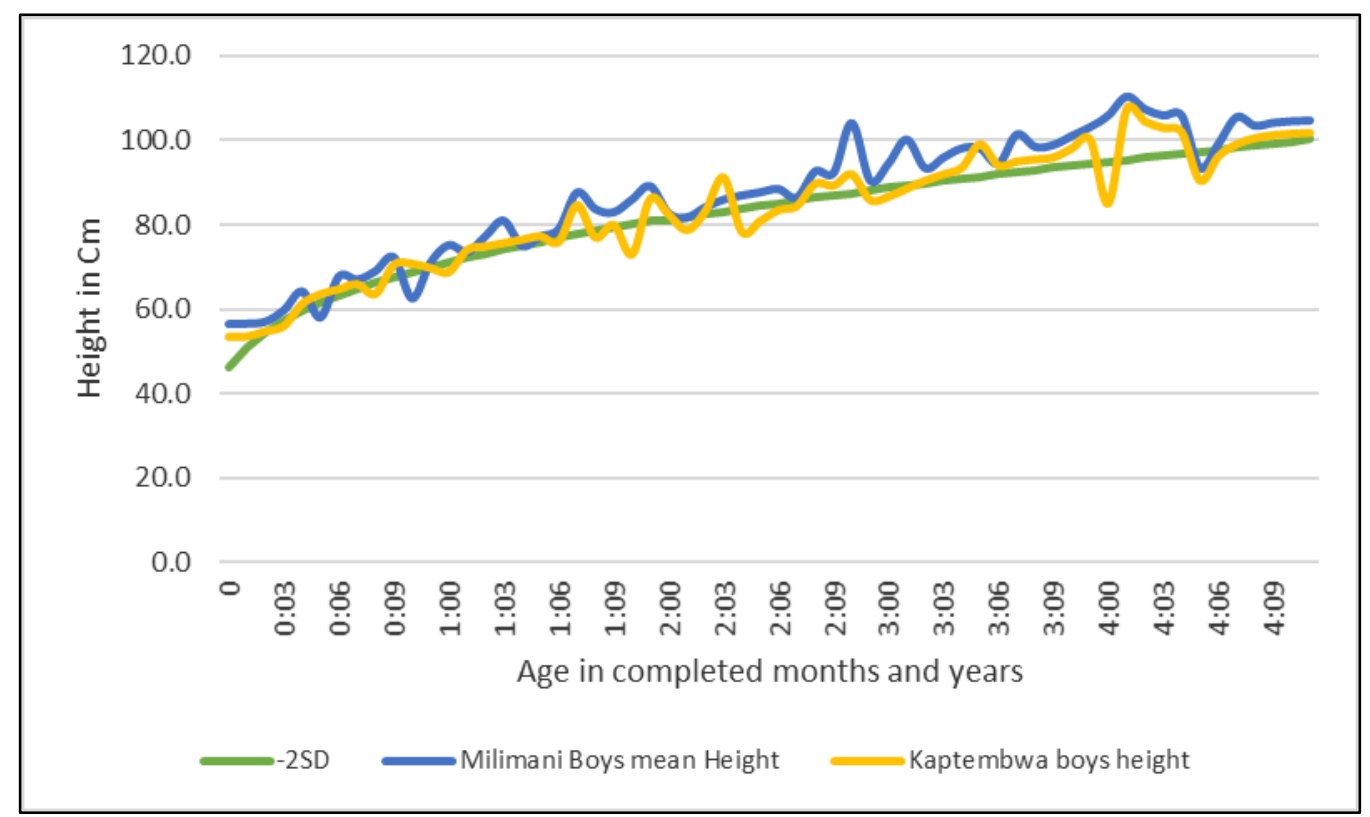

Figure 2: Height-for-age for boys in Kaptembwo and Milimani, Comparison of Actual Height with -2SD

The number of boys stunted in Milimani is low (5\%) compared to the number of boys stunted in Kaptembwo (30\%). The low number of stunting in Milimani is also recorded for girls (1.67\%) compared to the number of girls stunted in Kaptembwo (20\%).

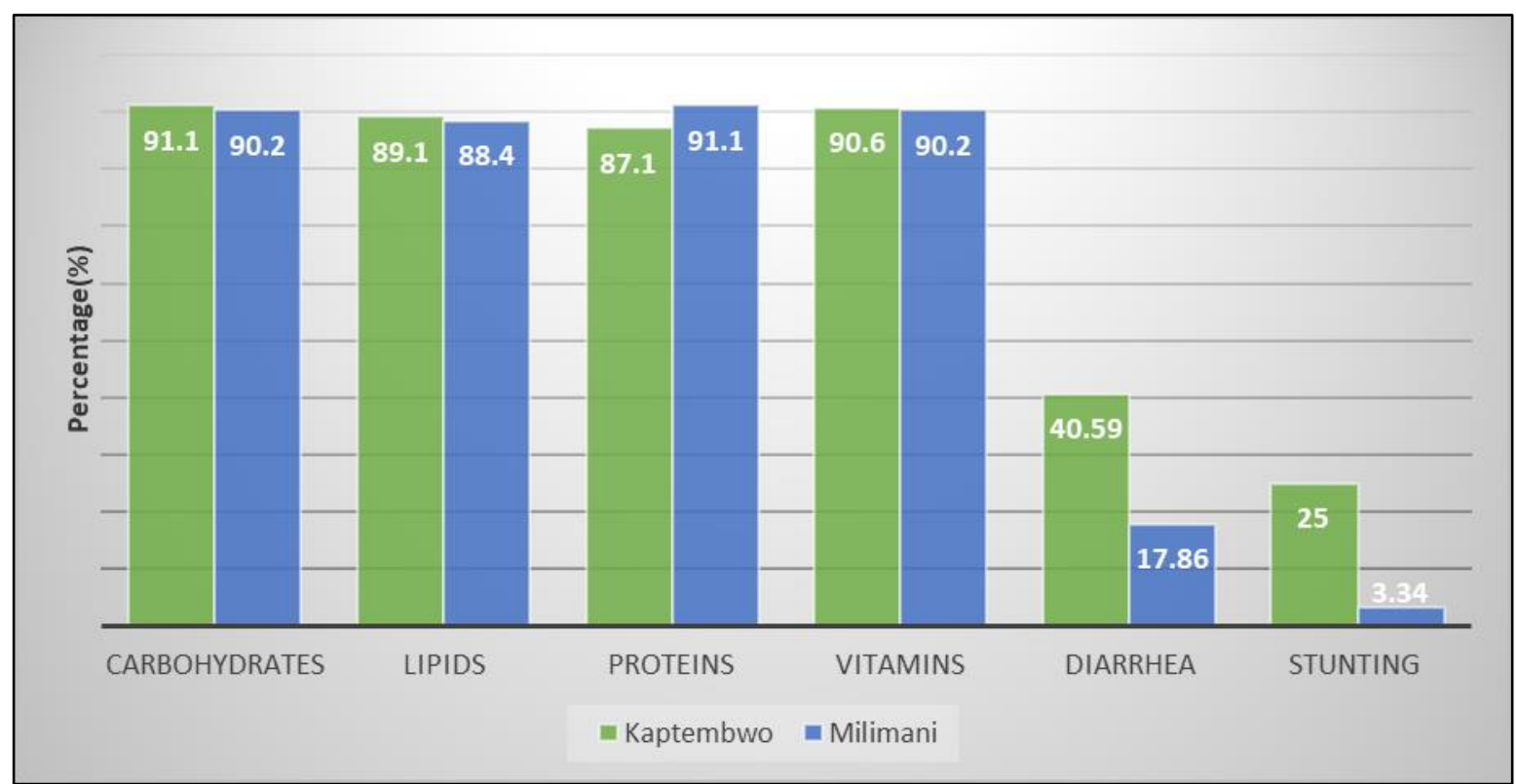

Figure 3: Comparison of Dietary Intakes, Diarrhoeal Episodes,

Stunting levels in both Kaptembwa and Milimani 


\section{Discussions}

The study sought to evaluate the role of environmental enteric dysfunction in stunting of fewer than five. Consent was sought from mothers or caregivers, as the test subjects were minors. Results showed that dietary intakes for Kaptembwo and Milimani are not significantly different $(\mathrm{P}>0.05)$, but the levels of stunting in Kaptembwo are higher $(25 \%)$ than the stunting levels in Milimani (3.335\%). These results are usually unexpected, especially when the dietary intakes are the same. Under normal circumstances, it is expected that children who take almost the same dietary intakes exhibit close growth patterns. Therefore, Environmental Enteric dysfunction has a positive role in stunting of children under five.

The study revealed that in both Kaptembwo and Milimani, boys are more stunted than girls. These findings concurs with findings of the study by Grace A. K. Ettyang and Caroline J. Sawe, (2016), on factors associated with stunting in children under 2 years in the Cambodia and Kenya, which found higher risk of stunting in males than in females. The results of this study showed that stunting in both males and females started in the second year of life. This finding differs with a study by Adair and Guilkey (1997), which show that males are more likely to become stunted in the first year of life.

Episodes of diarrhea were high in Kaptembwo (40.59\%) than in Milimani (12.86\%) episodes environmental factors which contribute to diarrhoea took centre stage in manipulating the desired effects of adequate dietary intakes and thereby causing stunting. This finding agrees with Mbuya \& Humphrey, (2016), who suggest that a nutritionally adequate diet for child is necessary but not enough for ensuring optimal linear growth. This means that children in Kaptembwo loss more nutrients through diarrhea than children in Milimani. Episodes of diarrhoea significantly reduce the absorptive capacity of the small intestine; hence fewer nutrients are available for utilization in the body. This characteristic was strongly associated with stunting.

The high episodes of diarrhea in Kaptembwo are attributed to poor environmental conditions such as unsafe drinking water, lack of sanitation and poor hygiene. This agrees with Prus-Ustun and Corvalan, (2006), who found that an estimated 94\% of the diarrheal burden of disease is attributed to the environment, and associated with risk factors such as unsafe drinking water, lack of sanitation and poor hygiene.

\section{Conflict of Interest}

Authors declare no conflict of interest.

\section{About the Author(s) \\ Daniel Matoke}

MSc-[C], BSc -Biomedical sciences, PGD-Nutrition and Dietetics, Lecturer, Kenya Medical Training College, Kenya. 


\section{Muthuka John Kyalo}

PhD Fellow \& Lecturer, College of Health Sciences, Jomo Kenyatta University of Agriculture \& Technology, Kenya (BSc, MPH, PGD-Biotech, Pharm-D, D. Nutr-Medicine, and PhD-Fellow) is health specialist in diverse areas. John has his interest in HIV/AIDS, maternal, child and neonatal $(\mathrm{MCNH})$, reproductive and adolescent health as well as neglected tropical diseases.

\section{Job O. Mapesa (PhD)}

Chairman of the Department, Kenya Methodist University, Nairobi, Kenya.

\section{Eglah Jerotich Kiplagat}

Deputy Registrar \& Lecturer at Kenya Medical Training College, Nairobi, Kenya. She is a nutrition specialist and health educator with over 20 years experience in academia and other health settings. Her key interests are on nutrition interventions, livelihoods and $\mathrm{MCH}$.

\section{MSc Lawrence Mugambi}

Lecturer, Kenya Methodist University, Nairobi, Kenya, His interest are public health, human nutrition and dietetics.

\section{References}

Adair, L. S., Guilkey, D. K. (1997). Age-specific determinants of stunting in Filipino children. The journal of nutrition, 127(2), 314-320. doi:10.1093/jn/127.2.314

Alderman, H., John Hoddinott, J., Kinsey, B. (2006). Long term consequences of early childhood malnutrition, Oxford Economic Papers, Volume 58, Issue 3, July 2006, Pages 450-474, doi: 10.1093/oep/gp1008.

Caulfield, L. E., Onis, M. de., Blössner, M., Black, R. E., Under nutrition as an underlying cause of child deaths associated with diarrhea, pneumonia, malaria, and measles, The American Journal of Clinical Nutrition, Volume 80, Issue 1, July 2004, Pages 193 198. doi: 10.1093/ajcn/80.1.193.

Checkley, W., Buckley, G., Robert H.Gilman, R. H., Assis, A. M., Guerrant, R. L., Morris, S. S., Molback, K., Valentine-Branth, P., Lanata, C. F., Black, R. E. (2008). The childhood Malnutrition and infection Network, Multi-country analysis of the effects of diarrhea on childhood stunting, International journal of Epidemiology, Volume 37, issue 4, August 2008, p 816-830.

Crane, R. J., Jones K. D., \& Berkley, J. A. (2015). Environmental enteric dysfunction: an overview. Food Nutrition Bulletin, 36 (1), S76-S87. doi:10.1177/15648265150361S113

Ettyang, Grace A. K. and Caroline J. Sawe (2016). Factors associated with stunting in children under age 2 in the Cambodia and Kenya 2014 Demographic and Health Surveys. DHS Working Papers No. 126. Rockville, Maryland, USA: ICF International. Available at http://dhsprogram.com/pubs/pdf/WP126/WP126.pdf. 
Daniel Matoke Ayienda, Muthuka J. Kyalo, Job O. Mapesa, Lawrence Mugambi, Eglah J. Kiplagat

INFLUENCE OF DIETARY INTAKES, ‘WASH' AND DIARRHEAL MORBIDITY ON STUNTING AMONG CHILDREN BELOW FIVE YEARS IN NAKURU COUNTY: A CASE STUDY OF KAPTEMBWO AND MILIMANI, KENYA

Grantham-McGregor, S. M., Walker, S. P., Chang, S. M., Powell, C. A., Simonoff, E. (2007).

Early Childhood Stunting Is Associated with Poor Psychological Functioning in Late Adolescence and Effects Are Reduced by Psychosocial Stimulation, The Journal of Nutrition, Volume 137, Issue 11, November 2007, Pages 2464-2469, doi: 10.1093/jn/137.11.2464.

Kenya National Bureau of Statistics (2019). Kenya population and housing census volume

II: Distribution of population by administrative units. National Bureau of Statistics p.241.

Keusch, G. T. P. A., Troncale, F. J., (1972). Sub-Clinical malabsorption in Thailand. II. Intestinal absorption in American military and Peace Corps personnel. American Journal of Clinical Nutrition, 25(10),1067-79.

Keusch, G.T., Rosenberg, I. H., Denno, D. M., Duggan, C., Guerrant, R. L., Lavery, J. V.,Ryan, E. T. (2013). Implications of acquired environmental enteric dysfunction for growth and stunting in infants and children living in low-and middle income countries. Food and nutrition bulletin, 34(3), 357-364. Doi:10.1177/156482651303400308.

Lindenbaum J. (1973). Tropical enteropathy. Gastroenterology, 64(4), 637-652.

Lindenbaum, J. G. C., \& Kent, T. H. (1971). Recovery of small intestinal structure and function after residence in the tropics I. Studies in Peace Corps volunteers. Annals of international Medicine, 74(2), 218-22.

Lindenbaum, J. K. T., \& Sprinz, H. (1966). Malabsorption and jejunitis in American Peace Corps volunteers in Pakistan. Annals of International Medicine,65(6), 1201-9.

Maluccio, J. A., Hoddinott, J., Behrman, J. R., Martorell, R., Quisumbing, A. R., Stein, A. D., The Impact of Improving Nutrition During Early Childhood on Education among Guatemalan Adults, The Economic Journal, Volume 119, Issue 537, 1 April 2009, Pages 734-763, doi: 10.1111/j.1468-0297.2009.02220.x

Mapesa, J. O., Maxwell, A. L., \& Ryan, E. P. (2016). An exposome perspective on environmental enteric dysfunction. Environmental health perspectives, 124(8), 1121. doi:10.1289/ehp.1510459

Mbuya, M. N., \& Humphrey, J. H. (2016).Preventing environmental enteric dysfunction through improved water, sanitation and hygiene: an opportunity for stunting reduction in developing countries. Maternal $\mathcal{E}$ Child Nutrition, 12 (Suppl 1), 106120. doi: $10.1111 / \mathrm{mcn} .12220$

Nshimyiryo, A., Hedt-Gauthier, B., Muaganzwa, C., Kirk, C. M. (2019). Risk factors for stunting among children under five years: a cross-sectional population based study in Rwanda using the 2015 Demographic and Health Survey. BMC Public Health 19, 175. doi: 10: 1186/s12889-019-6504-z

Prendergas A., Kelly. P. (2012). Enteropathies in the developing world: Neglected effects on global health; The American Journal of Tropical Medicine and Hygiene, Volume 86, Issue 5, 1 May 2012, p. 756 - 763. doi:10.4269/ajtmh.2012.11-0743. 
Prendergast, A. J., \& Humphrey, J. H. (2014). The stunting syndrome in developing countries. Paediatrics and international child health,34(4), 250-265. doi: 10.1179/2046905514Y.0000000158

Prüss-Üstün, Annette, Wolf, J., Corvalán, Carlos F., Bos, R. \& Neira, Maria Purificación. (2016). Preventing disease through healthy environments: a global assessment of the burden of disease from environmental risks. World Health Organization. https://apps.who.int/iris/handle/10665/204585.

United Nations' Children Fund, World Health Organisation, World Bank. Joint Child Malnutrition Estimated-Levels and Trends. Geneva, Switzerland: World Health Organisation, 2017. 
Creative Commons licensing terms

Author(s) will retain the copyright of their published articles agreeing that a Creative Commons Attribution 4.0 International License (CC BY 4.0) terms will be applied to their work. Under the terms of this license, no permission is required from the author(s) or publisher for members of the community to copy, distribute, transmit or adapt the article content, providing a proper, prominent and unambiguous attribution to the authors in a manner that makes clear that the materials are being reused under permission of a Creative Commons License. Views, opinions and conclusions expressed in this research article are views, opinions and conclusions of the author(s). Open Access Publishing Group and European Journal of Fitness, Nutrition and Sport Medicine Studies shall not be responsible or answerable for any loss, damage or liability caused in relation to/arising out of conflicts of interest, copyright violations and inappropriate or inaccurate use of any kind content related or integrated into the research work. All the published works are meeting the Open Access Publishing requirements and can be freely accessed, shared, modified, distributed and used in educational, commercial and non-commercial purposes under a Creative Commons Attribution 4.0 International License (CC BY 4.0). 